\title{
Effect of fermented bamboo shoot on the quality and shelf life of nuggets prepared from desi spent hen
}

\author{
Ankur Das, Dilip Ranjan Nath, Sabita Kumari and Rupu Saha \\ College of Veterinary Science, \\ Assam Agricultural University, Khanapara, Guwahati - 781 022, Assam, India \\ Corresponding author: Ankur Das, email:drankur0000@yahoo.co.uk \\ Received: 05-10-2012, Accepted: 03-12-2012, Published online: 20-04-2013
}

\section{How to cite this article:}

Das A, Nath DR, Kumari S and Saha R (2013) Effect of fermented bamboo shoot on the quality and shelf life of nuggets prepared from desi spent hen, Vet World 6(7):419-423, doi: 10.5455/vetworld.2013.419-423

\begin{abstract}
Aim: An investigation was carried out to prepare nuggets from the relatively tough and fibrous meat of desi spent hen using fermented bamboo shoot as a phytopreservative in order to enhance the physico-chemical, microbiological and keeping quality of the nuggets.

Materials and Methods: Lean meat of desi spent hen was minced and blended along with other non-meat ingredients and fermented bamboo shoot @ 10\%. The emulsion was filled in metallic moulds and steam cooked and cut into pieces. Ready-toeat nuggets thus prepared were packed in sterilized LDPE zip bags and stored at $4 \pm 1^{\circ} \mathrm{C}$ up-to 15 days for quality evaluation. Emulsion stability (\%), cooking yield (\%), $\mathrm{a}_{\mathrm{w}}$ and proximate composition were studied on the day of preparation, while estimation of $\mathrm{pH}$, TBA values, microbial load and sensory evaluation were carried out at 5 days interval and up-to $15^{\text {th }}$ day of storage.

Results: The emulsion stability (\%), cooking yield (\%), moisture (\%), crude protein (\%) and total ash (\%) of FBS treated nuggets differed significantly $(\mathrm{p}<0.01)$ from the control products. Storage studies revealed significantly lower $(\mathrm{p}<0.01) \mathrm{pH}$, TBA value, total plate count, psychrophillic count and counts for yeast and moulds in FBS treated nuggets in comparison to control products. Both control and treated nuggets exhibited gradual loss of panel ratings during the storage period $\left(4 \pm 1^{\circ} \mathrm{C}\right.$ for 15 days), however, nuggets containing fermented bamboo shoot revealed significantly higher $(\mathrm{p}<0.01)$ mean sensory scores in terms of flavour, texture, juiciness and overall acceptability.
\end{abstract}

Conclusion: Nuggets with better physico-chemical and shelf life can be prepared with incorporation of fermented bamboo shoot @ 10\% (w/w) to the nugget emulsion.

Key Words: desi spent hen, fermented bamboo shoot, nugget, phytopreservative

\section{Introduction}

The ever growing demand for meat and meat products and the increasing awareness amongst the consumers regarding various ailments arising from the consumption of processed foods of animal origin containing different chemical preservative are one of the issues which have been bothering food processors for decades. Now-a-days consumer demands meat products which are highly nutritious, microbiologically safe and free from health threatening chemical/ artificial agents [1]. Consequence to this, more emphasis are now being paid to those agents of biological origin which can retain the quality of meat food almost with no side affect and in this context fermented bamboo shoot (FBS) has come to the fore front as an effective phytopreservative yet to be exploited fully.

Since time immemorial, FBS are being used by the people of North East Region of India in the preparation of various delicious dishes. Some of the traditional fermented bamboo shoot products like

This article is an open access article licensed under the terms of the Creative Commons Attribution License (http://creativecommons. org/licenses/by/2.0) which permits unrestricted use, distribution and reproduction in any medium, provided the work is properly cited.
Soidon, Soibum and Soijim in Manipur, Mesu in Sikkim, Rep in Mizoram, Lung-siej/Syrwa in Meghalaya are traditionally consumed by the people of their respective states besides other adjoining areas/ states of NER [2]. Incorporation of FBS imparts a characteristic typical flavor and tangy taste to meat food products and for which these products are gaining increased popularity over the years. Moreover, bamboo shoots have been recognized to possess various health beneficial properties i.e. antibacterial, antifungal, antioxidant etc. [3], thereby, opening a new opportunity to utilize the same in formulation/ preparation of functional foods.

Nugget is a comminuted meat product with better acceptability and can be prepared suitably and economically by using the tough and fibrous meat of spent chicken having a very little market demand and acceptability to the consumers. It is in this context an attempt was made to prepare chicken nuggets with the incorporation of FBS and the products prepared were evaluated for their certain physico-chemical, microbiological and sensory qualities.

\section{Materials and Methods}

Dressed desi spent hens were procured from the 
local Beltola market of the Guwahati city and on manual deboning the meat was packed in low density polyethylene (LDPE) zip bags and stored at $4 \pm 1^{\circ} \mathrm{C}$ till required for use. Best quality spices viz. cumin, black pepper, coriander seeds, bay leaf and condiments were procured locally and thereafter the spices were thoroughly cleaned and dried in a hot air oven maintained at $45^{\circ} \mathrm{C}$ for $1 \frac{1}{2}$ hour. The grinding of the spices were done in a domestic Mixer Grinder at 1400 rpm for 1 minute to make a fine powder and stored in a airtight container. Condiments viz. Onion, garlic, ginger were cleaned/ peeled and separately mashed to a fine paste and were mixed in the ratio of $4: 2: 1$. For preparation of each batch of nuggets, condiments paste prepared afresh was used.

Preparation of FBS: Tender bamboo shoots of a local bamboo variety called 'Bhaluka Bah' (Bamboosa auriculata) were collected from in and around Guwahati city and also from the adjoining districts of Kamrup during the monsoon season of the year. These tender bamboo shoots were thoroughly washed, peeled, cleaned and grated. These grated bamboo shoots were placed in covered glass jars and allowed to ferment naturally at ambient temperature for about 2 months under a shed. During the maturation period, when the bamboo shoots produce a typical acidic flavour, it is indicative of completion of the fermentation process.

Standardization of FBS levels: A pilot study was conducted to evaluate the most desired levels of incorporation of FBS in the nugget emulsion. The basic recipe for both the control as well as the treated nuggets was kept same. However, for the treated nugget emulsion, FBS paste was incorporated at 7.5, 10 and $12.5 \%$ levels. The nuggets thus prepared were subjected to taste panel evaluation by employing semitrained panel of 11 judges and also by consumers' panel. Sensory evaluation studies revealed that nuggets prepared with $10 \%$ FBS were more acceptable and henceforth, nuggets were prepared by incorporation of FBS at $10 \%$ level. The prepared nuggets were then evaluated for various quality parameters included in the study.

Preparation of the Nuggets: Deboned meat was cut into small cubes and was minced thoroughly with the help of a manual meat mincer using $5 \mathrm{~mm}$ and $3 \mathrm{~mm}$ plates. The minced meat was then mixed thoroughly with non-meat ingredients. Control product contained refined soybean oil- $8 \%$, corn flour- $5 \%$, spices mix$1.5 \%$, condiments- $5 \%$, ice flakes- $5 \%$, skim milk- $2 \%$, common salt-2\% and sodium nitrite@150 ppm. Formulation of treated nuggets comprised of $10 \%$ FBS, besides, the other non-meat ingredients as was used in the control formulation. All the ingredients of both the control and treated formulations were mixed thoroughly and bowl chopped at low speed for 1 minute and then at high speed for 2 minutes to make a fine emulsion.
Meat emulsion (previously weighed) thus prepared were filled in oil coated metallic moulds $\{8 "(\mathrm{~L}) \times 5 "(\mathrm{~B}) \times 4 "(\mathrm{H})\}$ with lids and steam cooked for 45 minutes at $5 \mathrm{lb}$ pressure to a core temperature of $70^{\circ} \mathrm{C}$. On completion of cooking, the moulds were allowed to cool down at room temperature and the moulded meat block was carefully taken out and weighed. It was then sliced and cut into nuggets of $4 \times 2$ $\mathrm{x} 2 \mathrm{~cm}$ size and packed in sterilized LDPE zip bags and stored under refrigeration at $4 \pm 1^{\circ} \mathrm{C}$.

The $\%$ emulsion stability of the product was determined as per the method of Baliga and Madaiah [4] with slight modification [instead of polyethylene bags airtight polypropylene jars (Make: TARSONS, Capacity: 125ml) were used to cook the nugget samples $\}$. The \% Cooking yield was calculated as per the method of Putra et. al. [5] while the water activity $\left(a_{w}\right)$ was determined by a technique as described by Labuza et al. [6]. Proximate composition encompassing moisture, crude protein, ether extract and total ash content of the nuggets were determined as per the AOAC [7]. The $\mathrm{pH}$ value of the nuggets were determined using a probe type digital $\mathrm{pH}$ meter (Systronics, Model 335) and the thiobarbituric acid (TBA) value of the product was determined by using a Spectrophotometer at $530 \mathrm{~nm}$ following the standard method as described by Witte et al., [8]. Sensory attributes comprising of colour, flavour, texture, juiciness and overall acceptability were determined by employing a 11 member semi-trained panel of judges and by using a 8-point hedonic scale [9].

The total plate count (TPC), psychrophilic count (PC) and the counts for yeast and moulds were carried out as per the methods of APHA [10]. The results were expressed as log cfu (colony forming unit) per $g$ of meat. Standard plate count agar (Make: HiMedia, Code- M091) and Rose bengal chloramphenicol agar (Make: HiMedia, Code- M640) were used for total viable plate count, psychrophilic count, yeast and mould counts respectively.

The shelf life study was carried out by keeping the nuggets under refrigeration (at $4 \pm 1^{\circ} \mathrm{C}$ ) for 15 days. During the storage period, the nuggets were evaluated for $\mathrm{pH}, \mathrm{TBA}$ values, microbiological and sensory qualities at an interval of 5 days and up-to 15 days.

Statistical analysis: For all the parameters, an average of 3 replicates was recorded and the data thus obtained were analyzed as per the method of Snedecor and Cochran [11].

\section{Results and Discussion}

A significantly higher $(p<0.01)$ emulsion stability $(\%)$ and cooking yield (\%) of the FBS treated nuggets as compared to the control product were recorded in the study. However, the mean $a_{w}$ values recorded were almost similar in both the control and treated products (Table-1). Higher emulsion stability recorded in FBS treated nuggets might be ascribed to higher content of 
Table-1. Effect of addition of fermented bamboo shoot on the Physico-chemical properties of desi spent hen nuggets.

\begin{tabular}{lll}
\hline Parameter & Control Product & Treated Product \\
\hline Emulsion Stability\% & $93.24^{\mathrm{a}} \pm 0.22$ & $98.24^{\mathrm{b}} \pm 0.37$ \\
Cooking Yield\% & $95.13^{\mathrm{a}} \pm 0.14$ & $97.85^{\mathrm{b}} \pm 0.51$ \\
$\mathrm{a}_{\mathrm{w}}$ & $0.972 \pm 0.54$ & $0.978 \pm 0.43$ \\
Moisture & $64.68^{\mathrm{a}} \pm 0.39$ & $66.05^{\mathrm{b}} \pm 0.12$ \\
Crude Protein & $15.24^{\mathrm{a}} \pm 0.27$ & $17.83^{\mathrm{b}} \pm 0.36$ \\
Ether Extract & $12.34 \pm 0.54$ & $12.39 \pm 0.46$ \\
Total Ash & $2.47^{\mathrm{a}} \pm 0.21$ & $3.51^{\mathrm{b}} \pm 0.37$ \\
\hline
\end{tabular}

Means bearing no-superscript do not differ significantly $(p<0.01)$

Table-2. Effect of fermented bamboo shoot on the quality attributes of desi spent hen nuggets during storage.

\begin{tabular}{|c|c|c|c|c|c|}
\hline Particulars & $1^{\text {st }}$ Day & $5^{\text {th }}$ Day & $10^{\text {th }}$ Day & $15^{\text {th }}$ Day & Treatment Mean \\
\hline \multicolumn{6}{|l|}{$\overline{\mathrm{pH}}$} \\
\hline $\mathrm{C}$ & $6.09 \pm 0.06$ & $6.19 \pm 0.02$ & $6.35 \pm 0.06$ & $6.66 \pm 0.11$ & $6.33^{\mathrm{a}} \pm 0.11$ \\
\hline $\mathrm{T}$ & $5.18 \pm 0.03$ & $5.3 \pm 0.02$ & $5.53 \pm 0.11$ & $5.85 \pm 0.11$ & $5.47^{\mathrm{b}} \pm 0.14$ \\
\hline \multicolumn{6}{|c|}{ TBA Values (mg malanoldehyde/ kg) } \\
\hline $\mathrm{C}$ & $0.27^{\mathrm{a}} \pm 0.05$ & $0.53^{\mathrm{ab}} \pm 0.06$ & $0.84^{\mathrm{c}} \pm 0.04$ & $1.39^{d} \pm 0.10$ & $0.76^{a} \pm 0.20$ \\
\hline \multirow{2}{*}{\multicolumn{6}{|c|}{ TPC $(\log \mathrm{cfu} / \mathrm{g})$}} \\
\hline & & & & & \\
\hline C & $2.45^{\mathrm{a}} \pm 0.08$ & $3.52^{\mathrm{a}} \pm 0.10$ & $4.67^{\mathrm{b}} \pm 0.24$ & $6.52^{c} \pm 0.13$ & $4.29^{\mathrm{a}} \pm 0.70$ \\
\hline T & $2.37 \pm 0.08$ & $2.61 \pm 0.12$ & $2.98 \pm 0.09$ & $3.18 \pm 0.07$ & $2.78^{\mathrm{b}} \pm 0.17$ \\
\hline $\begin{array}{l}\text { PC }(\log \mathrm{cfu} / \\
\mathrm{C}\end{array}$ & $232^{a}+0.09$ & \multicolumn{4}{|c|}{ PC (log cfu/g) } \\
\hline $\mathrm{T}$ & $2.09 \pm 0.04$ & $\begin{array}{l}2.09 \pm 0.10 \\
2.21 \pm 0.06\end{array}$ & $\begin{array}{l}0.200 \pm 0.00 \\
2.39 \pm 0.07\end{array}$ & $2.61 \pm 0.07$ & $2.32^{\mathrm{b}} \pm 0.11$ \\
\hline \multicolumn{6}{|c|}{ Yeast and Moulds (log cfu/g) } \\
\hline C & $0.00 \pm 0.00$ & $1.15^{\mathrm{a}} \pm 0.05$ & $2.24^{\mathrm{b}} \pm 0.08$ & $2.52^{\mathrm{b}} \pm 0.09$ & $1.48^{\mathrm{a}} \pm 0.46$ \\
\hline $\mathrm{T}$ & $0.00 \pm 0.00$ & $0.00 \pm 0.00$ & $1.47 \pm 0.03$ & $1.83 \pm 0.01$ & $0.83^{\mathrm{b}} \pm 0.74$ \\
\hline
\end{tabular}

Means bearing no-superscript do not differ significantly $(p<0.01)$

dietary fiber in the FBS [3]. Choi et. al. [12] and Talukdar and Sharma [13] also reported that addition of dietary fiber in the meat products significantly enhance the emulsion stability. The significantly higher $(p<0.01)$ cooking yield recorded in the FBS treated nuggets might also be attributed to the higher dietary fiber content in the FBS and for which more moisture was retained in the meat matrix during cooking. The results obtained in the study corroborated well with the reports of Sánchez-Zapata et. al. [14] in preparing pork burger with tiger nut fibre. On proximate analysis, significantly higher $(p<0.01)$ contents of moisture, crude protein and total ash was recorded in the FBS treated nuggets as compared to the control product. The higher moisture content in the FBS treated nuggets might be a corollary to the higher moisture content in FBS [3]. Registering of higher crude protein and total ash content in treated products as compared to the control ones might be ascribed to the contribution of these two proximate principles by the addition of FBS [3].

Both the control and treated nuggets exhibited a gradual but non-significant rise in their $\mathrm{pH}$ values (Table-2) from day 1 to the $15^{\text {th }}$ day. The initial low $\mathrm{pH}$ of the treated nuggets might be due to the inherent acidity of the FBS [15]. Subsequent increase in the $\mathrm{pH}$ values of both the control and treated nuggets on storage could be due to the accumulation of nitrogenous substances consequence to the protein breakdown. The results obtained in respect of $\mathrm{pH}$ in the present study are well in agreement with the reports of Kumar and Tanwar [1]. Again significantly lower $(p<0.01)$ TBA values (Table-2) were recorded in nuggets containing FBS as compared to the control products throughout the period of storage. The antioxidant properties of the FBS which contains two potent antioxidants viz. Tricin and Taxifolin [16] might have retarded the lipolytic activity in the treated nuggets resulting in recording of lower TBA values. The results of the present study had further strengthened the reports of Chavhan [17] who also reported that FBS can retain the TBARS values of pork pickle within the acceptable limit even up-to 90 days of storage.

Microbial loads (Table-2) showed a progressive increasing trend during the storage period in both the control and treated nuggets. However, the mean TPC, $\mathrm{PC}$ and counts for yeast and moulds during the storage period were significantly lower $(p<0.01)$ in FBS treated nuggets as compared to the control ones. The lower microbial counts (TPC, PC and counts for yeast and moulds) in the FBS treated nuggets might be due to the antimicrobial effect of FBS [15,18]. Moreover, antifungal properties of FBS might have also contributed in recording of decreased yeast and moulds counts [19]. This is in close agreements with the reports of Changmai [20] who also recorded decreased yeast and moulds counts during the production of ready-toeat cooked smoked pork product with the addition of FBS.

Studies on sensory attributes of the nuggets revealed that product prepared with FBS scored significantly higher mean $(p<0.01)$ panel ratings as compared to the control product in terms of flavour, texture, juiciness and overall acceptability throughout 
Table 3. Effect of fermented bamboo shoot on sensory attributes of desi spent hen nuggets during storage.

\begin{tabular}{|c|c|c|c|c|c|}
\hline Particulars & $1^{\text {st }}$ Day & $5^{\text {th }}$ Day & $10^{\text {th }}$ Day & $15^{\text {th }}$ Day & Treatment Mean \\
\hline \multicolumn{6}{|l|}{ Colour } \\
\hline $\mathrm{C}$ & $6.87 \pm 0.15$ & $6.65 \pm 0.10$ & $6.36 \pm 0.09$ & $6.14 \pm 0.09$ & $6.51^{\mathrm{a}} \pm 0.11$ \\
\hline \multirow{2}{*}{\multicolumn{6}{|c|}{ Flavour }} \\
\hline & & & & & \\
\hline C & $6.71^{\mathrm{a}} \pm 0.14$ & $6.42^{\mathrm{a}} \pm 0.09$ & $5.91^{\mathrm{b}} \pm 0.11$ & $5.34^{\mathrm{C}} \pm 0.07$ & $6.10^{\mathrm{a}} \pm 0.13$ \\
\hline $\mathrm{T}$ & $7.21^{\mathrm{a}} \pm 0.11$ & $6.74^{\mathrm{b}} \pm 0.07$ & $6.63^{\mathrm{bc}} \pm 0.09$ & $6.29^{\mathrm{d}} \pm 0.09$ & $6.72^{\mathrm{b}} \pm 0.10$ \\
\hline \multicolumn{6}{|l|}{ Texture } \\
\hline C & $6.80^{\mathrm{a}} \pm 0.09$ & $6.38^{\mathrm{b}} \pm 0.12$ & $6.02^{c} \pm 0.11$ & $5.65^{\mathrm{d}} \pm 0.07$ & $6.21^{\mathrm{a}} \pm 0.11$ \\
\hline $\mathrm{T}$ & $7.25^{\mathrm{a}} \pm 0.05$ & $7.10^{\mathrm{ab}} \pm 0.07$ & $6.83^{b c} \pm 0.06$ & $6.50^{\mathrm{d}} \pm 0.06$ & $6.92^{b} \pm 0.10$ \\
\hline \multicolumn{6}{|l|}{ J uiciness } \\
\hline C & $6.65^{\mathrm{a}} \pm 0.09$ & $6.49^{\mathrm{ab}} \pm 0.08$ & $6.23^{\mathrm{c}} \pm 0.06$ & $6.01^{\mathrm{cd}} \pm 0.06$ & $6.35^{\mathrm{a}} \pm 0.08$ \\
\hline $\mathrm{T}$ & $7.34^{\mathrm{a}} \pm 0.11$ & $7.16^{\mathrm{ab}} \pm 0.08$ & $6.92^{\mathrm{bc}} \pm 0.05$ & $6.76^{\text {cd }} \pm 0.06$ & $7.05^{\mathrm{b}} \pm 0.08$ \\
\hline \multicolumn{6}{|c|}{ Overall acceptability } \\
\hline C & $6.71^{a} \pm 0.06$ & $6.49^{\mathrm{a}} \pm 0.08$ & $6.18^{b} \pm 0.06$ & $5.90^{c} \pm 0.06$ & $6.32^{\mathrm{a}} \pm 0.08$ \\
\hline $\mathrm{T}$ & $7.14^{\mathrm{a}} \pm 0.10$ & $7.03^{\mathrm{ab}} \pm 0.06$ & $6.81^{\mathrm{bc}} \pm 0.05$ & $6.60^{\mathrm{cd}} \pm 0.07$ & $6.90^{\mathrm{b}} \pm 0.07$ \\
\hline
\end{tabular}

Means bearing no-superscript do not differ significantly $(p<0.01)$

the storage period. The differences in the color scores of the control and treated nuggets though were found to be non-significant, yet, the FBS treated nuggets recorded marginally higher score than its control counterpart. Such differences in the color scores might be attributed to the polyphenol compounds of bamboo shoots [21] and its interaction with the curing ingredients.

The significantly higher $(p<0.01)$ mean flavor scores of the treated nuggets might be attributed to the peculiar aromatic smell inherited by the FBS. Gradual reduction in the flavor scores recorded in both the control and treated nuggets might be due to oxidative reaction and associated growth and multiplication of microbes during the storage period. However, the decrease in flavor scores was much slow in the treated nuggets which could be correlated to the anti-oxidative effect of FBS [16]. The mean texture scores in the FBS treated nuggets were significantly higher $(p<0.01)$ and this might be related to the dietary fibre content of FBS [3] that had contributed in better emulsion formation [13] and improvement in texture. The study revealed a significant decrease $(p<0.01)$ in the juiciness scores with the progression of storage period in both the control and treated products. The mean juiciness scores for the treated nuggets were however significantly higher $(p<0.01)$ as compared to the control product. Higher moisture content besides better moisture absorbing properties of dietary fibers present in the FBS [3] might have contributed to this. The mean overall acceptability scores of the FBS treated nuggets were also significantly higher $(p<0.01)$ than their control counterparts and this might be related to the awarding of corresponding better scores for flavour, texture and juiciness by the panelists. All the sensory parameters included in the present study exhibited a gradual decline in their panel scores and are in conformity to the findings of Biswas et. al. [22] and Kumar \& Tanwar [1].

\section{Conclusion}

Based on the results obtained in the present investigation, it might be concluded that FBS treated nuggets were superior to the control product and the addition of FBS @ 10\% (w/w) had given the most promising physicochemical, microbial and sensory qualities in spent chicken nuggets that could be suitably stored for 15 days under refrigeration $\left(4 \pm 1^{\circ} \mathrm{C}\right)$.

\section{Authors' contribution}

AD planned and carried out the research work. DRN drafted and revised the Manuscript and done the statistical analysis of the data. SK and RS tested the samples. All authors read and approved the final manuscript.

\section{Acknowledgements}

The authors are thankful to the Dean, College of Veterinary Science, Assam Agricultural University, Khanapara, Guwahati - 781022, Assam, India for providing necessary laboratory facility to carry out the study.

\section{Competing interests}

Authors declare that they have no competing interest.

\section{References}

1. Kumar D. and Tanwar V. K. (2011) Effects of incorporation of ground mustard on quality attributes of chicken nuggets. $J$. Food Sci. Technol., 48(6):759-762. DOI 10.1007/s13197010-0149-3.

2. Jayaram K., Singh Th. A., Romi W., Devi R. A., Singh W. M., Dayanidhi H, Singh N. R. and Tamang J. P. (2009) Traditional Fermented Foods of Manipur, Indian J. Trad. Knowl., 8(1): 115-121.

3. Nirmala C.; Bisht M. A. and Haorongbam S. (2011) Nutritional Properties of Bamboo Shoots: Potential and Prospects for Utilization as a Health Food. Compre. Rev. Food Sci. Food Safety, 10: 153-169.

4. Baliga B. R. and Madaiah N. (1971) Preparation of mutton sausages. J. Food Sci., 36: 607-610.

5. Putra, A. A., Huda, N. and Ahmad, R. (2011) Changes During the Processing of Duck Meatballs Using Different Fillers after the Preheating and Heating Process. Int. J. Poultry Sci., 10(1): 62-70.

6. Labuza T. P., Acott K., Tatini S. R., Lee R.Y., Flink J. M. and Mc Call W. (1976) Water Activity Determination: A Collaborative Study of Different Methods. J. Food Sci., 46:1687.

7. A.O.A.C. (2007) Official Methods of analysis of the 
Association of Official Analytical Chemist, 18th Edn., USDA, Washington, D.C.

8. Witte V. G., Krause G. F. and Barley M. E. (1970) A new extraction method for 2-thiobarbituric acid value for pork and beef during storage. J. Food Sci., 35:582 -583.

9. Keeton J. T., Foegeding E. A. and Patina A. C. (1984) A Comparison of Nonmeat Products, Sodium Tripolyphosphate and Processing Temperature Effects on Physical and Sensory Properties of Frank Furthers. J. Food Sci., 49: 1462-1474.

10. APHA (1992) In: Vandergrant C, Splittstoesser DF (eds) Compendium of methods for the microbiological examination of foods, 4th edn. American Public Health Association, Washington DC, pp 919-927.

11. Snedecor, G. W. and Cochran, W. G. (1994) Statistical Methods, $1^{\text {st }}$ Edn., East West Press Pvt. Ltd., New Delhi.

12. Choi Y. S., Choi J. H., Han D. J., Kim H. Y., Lee M. A., Kim H. W., Jeong J. Y. and Kim C. J. (2009) Characteristics of low-fat meat emulsion systems with pork fat replaced by vegetable oils and rice bran fiber. Meat Sci., 82(2): 266-271.

13. Talukder, S. and Sharma, D. P. (2010) Development of dietary fiber rich chicken meat patties using wheat and oat bran. J. Food Sci. Technol., 47(2):224-229.

14. Sánchez-Zapata E., Muñoz C. M., Fuentes E., FernándezLópez J., Sendra E., Sayas E., Navarro C. and Pérez-Alvarez J.A. (2010) Effect of tiger nut fibre on quality characteristics of pork burger. Meat Sci., 85(1):70-6.

15. Hazarika M., Rahman H. and Hazarika D. (2008) Antibacterial activity of fermented bamboo shoot (Kharisa).
In Proc. 53th Annual Technical Session of Assam Science Society. Vol. 9, PP-135-142.

16. Katsuzaki H., Suki K., Achiwa Y., Imai K. and Komiya, T. (1999) Isolation of antioxidant compound from bamboo shoot sheath. J. Japanese Soci. Food Sci. Technol., 46(7): 491- 493 .

17. Chavhan D. M. (2008) Development of Fermented Pork Pickle with Fermented Bamboo Shoot. M.V.Sc. Thesis submitted to Assam Agricultural University, Khanapara, Guwahati-22, India.

18. Fujimura M., Ideguchi M., Minami Y., Watanabi K. and Tadera K. (2005) Amino acid sequence and antimicrobial activity of chitin binding peptides, Pp-AMP 1 and Pp-AMP2, from Japanese bamboo shoots (Phyllostachys pubescens). Biosci. Biotech. Biochem., 69:642-5.

19. Wang H. X. and Ng T. B. (2003) Dendrocin, a distinctive anti-fungal protein from bamboo shoots. Biochem. Biophys. Res. Commun., 307: 750-5.

20. Changmai S. (2005) Development of a ready-to-eat cooked smoked pork product. M.V.Sc. Thesis, Assam Agricultural University, C.V.Sc., Khanapara, Guwahati-22.

21. Lu B., Wu X., Shi J., Dong Y. and Zhang Y. (2006) Toxicology and safety of antioxidant of bamboo leaves. Part 2: developmental toxicity tests in rats with antioxidant of bamboo leaves. Food Chem. Toxicol., 44(10):1739-43.

22. Biswas S., Chakraborty A., Patra G. and Dhargupta A. (2011) Quality and acceptability of duck patties stored at ambient and refrigeration temperature. Int. J. Livestock Pro. 1(1):1-6.

$* * * * * * * *$ 